\title{
The impact of fire on habitat use by the short-snouted elephant shrew (Elephantulus brachyrhynchus) in North West Province, South Africa
}

\author{
Richard W. Yarnell ${ }^{*}$, Daniel J. Metcalfe ${ }^{2}$, Nigel Dunstone ${ }^{3}$, \\ Niall Burnside' \& Dawn M. Scott ${ }^{1}$ \\ ${ }^{1}$ Biology Division, University of Brighton, Cockcroft Building, Moulsecoomb, Brighton, BN1 2JG, U.K. \\ ${ }^{2}$ CSIRO Sustainable Ecosystems, Tropical Forest Research Centre, P.O. Box 780, Atherton, QLD 4883, Australia \\ ${ }^{3}$ Department of Zoology, University of Otago, P.O. Box 56, Great King street, Dunedin, New Zealand \\ Received 10 April 2007. Accepted 4 October 2007.
}

\begin{abstract}
Several studies have investigated the response of small mammal populations to fire, but few have investigated behavioural responses to habitat modification. In this study we investigated the impact of fire on home range, habitat use and activity patterns of the short-snouted elephant shrew (Elephantulus brachyrhynchus) by radio-tracking individuals before and after a fire event. All animals survived the passage of fire in termite mound refugia. Before the fire, grassland was used more than thickets, but habitat utilization shifted to thickets after fire had removed the grass cover. Thickets were an important refuge both pre- and post-fire, but the proportion of thicket within the home range was greater post-fire. We conclude that fire-induced habitat modification resulted in a restriction of $E$. brachyrhynchus movements to patches of unburned vegetation. This may be a behavioural response to an increase in predation pressure associated with a reduction in cover, rather than a lack of food. This study highlights the importance of considering the landscape mosaic in fire management and allowing sufficient island patches to remain post-fire ensures the persistence of the small mammal fauna.
\end{abstract}

Keywords: fire, Macroscelidea, habitat modification, habitat-use, South Africa.

\section{INTRODUCTION}

Fire is used extensively in southern Africa to remove residual dry matter, combat bush encroachment, and to maintain grassland heterogeneity and species composition (Whelan 1995; Brockett et al. 2001; Parr \& Chown 2003). However, the effects of fire on biodiversity, especially of small vertebrates, have rarely been addressed (though see Parr \& Chown 2003).

It is widely reported that fire has a negative impact on small mammal populations (Kern 1981; Clark \& Kaufman 1990; Friend 1993; Vieira 1999) either by killing animals directly (Esque et al. 2003) or indirectly by reductions in food resources or increased predation post-fire (Kern 1981). The result is usually a post-fire reduction in population size (Cheeseman \& Delany 1979; Vanhensbergen \& Martin 1993; Fuller \& Perrin 2001; Monadjem \& Perrin 2003). However, small mammals can survive fire by fleeing (Monadjem \& Perrin 1997) or seeking shelter in burrows (Kern 1981; Swanepoel 1981) or

*Author for correspondence. E-mail: rwyarnell@msn.com unburned patches (Bowland \& Perrin 1988).

Individuals that remain in post-fire environments face changes in habitat structure and complexity and distribution of resources, which can result in changes in behaviour. For example, the diurnal murid Lemniscomys striatus has been shown to become more active at night in post-fire grasslands in Uganda, possibly to avoid detection by diurnal predators (Hoffman \& Klingel 2001). Foraging costs may be greater with reduced cover and increased predation risk (Bowers \& Dooley 1993; Hughes et al. 1994; Taraborelli et al. 2003; Kotler et al. 2004). Diurnal species may also show a thermoregulatory response to the increased solar radiation (Hoffman \& Klingel 2001).

In general, fire research on small mammals is hindered by the lack of information on actual movements and individual responses during fire events (Sutherland \& Dickman 1999). Most studies have compared abundance based on live trapping, including mark-recapture, before and after fires. However, live trapping data are limited because 
they do not distinguish mortality from migration (Clark \& Kaufman 1990), whereas radio-tracking individuals during a fire can determine levels of mortality and migration in addition to shifts in activity and habitat use. This information is needed to develop methods of reducing fire impacts on small mammals.

Elephant shrews are now considered to represent an ancient monophyletic African radiation belonging to the Afrotherian clade and are grouped in the family Macroscelididae (Corbet \& Hanks 1968, Stuart et al. 2006). Whilst their ecology has received some attention, no previous studies have investigated the effect of fire on any elephant shrew species. The most numerous and widely distributed species is the short-snouted elephant shrew (Elephantulus brachyrhynchus) (Corbet \& Hanks 1968) which inhabits open woodland savanna habitats with dense ground cover and is thus susceptible to the impacts of fire (Rankin 1965; Neal 1995; Linzey \& Kesner 1997; Skinner \& Chimimba 2005; Leirs et al. 1995; Yarnell \& Scott 2006). Consequently, there is a need to understand the effect of current management fire regimes to ensure future management and conservation of E. brachyrhynchus populations.

In this study we determined survivorship during fire, as well as activity patterns, home range and habitat use before and after fire using radio-tracking. We hypothesize that E. brachyrhynchus survives the passage of fire by taking refuge and that its home range, habitat use or activity will alter in response to fire-induced habitat modification. We discuss our findings in the light of their implications for developing fire management regimes that consider small mammal conservation.

\section{METHODS}

\section{Study area}

Our study took place at Mankwe Wildlife Reserve, Northwest Province, South Africa. The reserve $\left(25^{\circ} 13^{\prime} \mathrm{S}, 27^{\circ} 18^{\prime} \mathrm{E}\right)$ covers an area of 4105 ha of relatively flat mixed-sourish mixed bushveld sensu Acocks (1975) east of the Pilanesberg massif. Climate is sub-arid, with annual rainfall c. $650 \mathrm{~mm}$, with $80 \%$ falling between October and February. Mean daily temperatures range from $c .11^{\circ} \mathrm{C}$ in July to c. $23^{\circ} \mathrm{C}$ in December. The study area was an abandoned sisal (Agave rigida) plantation, covering 66 ha, dominated by grass with remnant stands of sisal and scattered trees including acacias (Acacia tortilis, A. nilotica and A. mellifera), sickle bush (Dichrostachys cinerea), and combretum (Combretum sp.) that formed thickets. The grass layer pre-fire was dense and dominated by spear grass (Heteropogon contortus), red autumn grass (Schizachyrium jeffreysii), Natal red top (Melinis repens), three-awn grass (Aristida congesta) and yellow thatching grass (Hyperthelia dissoluta) (Yarnell 2005). We selected this site because it supported a mosaic of thicket and grassland habitats and had relatively high E. brachyrhynchus densities relative to the rest of the reserve (Yarnell 2005). Vegetation cover was surveyed using four $50 \times 50 \mathrm{~cm}$ quadrats in the trapping grid pre- and post-fire and percentage cover recorded by eye. Grass species composition was recorded by randomly walking a straight $250 \mathrm{~m}$ line transect through the grid and recording the nearest species every second step (Van Oudtshoorn 2002). The vegetation mosaic of the study area was mapped and digitized (ArcView 3.2 GIS (ESRI 1992)) both pre- and post-fire to calculate the extent, location and cover of thickets. To record the impact of the fire, fire pass rate and total area burnt were recorded.

The community of small-mammal predators recorded in the area included snakes, small carnivores and raptors. Predator abundance was not estimated, but assumed to be typical and representative of other intact southern African savannas. Rodents caught in the area included Aethomys ineptus, Lemniscomys rosalia, Mastomys coucha, Mus indutus and Tatera leucogaster (Yarnell 2006). Identification of Aethomys, Mastomys and Mus was determined via mitochondrial DNA analysis of 10 random samples of ear clips from each species.

\section{Radio-tracking}

To capture individuals, Sherman live-traps $(23 \mathrm{~cm} \times 9 \mathrm{~cm} \times 7.5 \mathrm{~cm}$, H.B. Sherman Traps Inc., Orlando, Florida) were placed in a $100 \times 120 \mathrm{~m}$ trapping grid (120 trap stations; one trap per station, spaced $10 \mathrm{~m}$ apart). Traps were operated for four days (480 trap nights) and baited with oats and peanut butter. Traps were set in the afternoon and checked daily in the morning. Traps were closed during the day to prevent animals suffering from hyperthermia (Scott \& Dunstone 2000). Fifteen E. brachyrhynchus were caught. All captured E. brachyrhynchus were given a unique fur clip and weighed (Scott \& Dunstone 2000). Animals were collared if they looked in good health and weighed $>40 \mathrm{~g}$. BioTrack (BioTrack Ltd. Dorset UK) radio transmitters attached to 
cable ties weighed $<2 \mathrm{~g}$ (i.e. $<5 \%$ body weight, Cockran (1980) and Kenward (1987)), were fitted by gentle restraint without anaesthesia. Radiotracking using a Telonics TR-4 receiver with $\mathrm{H}$-Adcock antenna took place over 24 hours during a four-week period during August 2004. The study area was burned by the reserve manager three weeks after radio-tracking had commenced. Radio-tracking continued after the burn for one week before the batteries of the collars expired. Trapping grid points were used as stations for triangulation. Error analysis showed bearings to have a mean error of $7.67^{\circ} \pm 5.96$ S.D. over an average distance of $30 \mathrm{~m}$ giving an error diameter per fix of $8 \mathrm{~m}$. Fixes were triangulated from at least three points at a minimum distance of $30 \mathrm{~m}$ from the individual and with a minimum time of 45 minutes between triangulations to minimize disturbance. Each day was divided into six, four-hour survey periods starting at 06:00, 10:00, 14:00 etc. Before the fire, 431 fixes were recorded in daylight and 125 at night for nine individuals. After the fire, 218 were recorded in daylight and 130 recorded at night for six individuals. Maximum and minimum temperatures were recorded daily, with mean daily maximum and minimum temperatures being $25^{\circ} \mathrm{C}$ (range 18 to $30^{\circ} \mathrm{C}$ ) and $4^{\circ} \mathrm{C}$ (range -3 to $7^{\circ} \mathrm{C}$ ), respectively. Full moon occurred at the beginning (2 August) and end of the study (31 August), therefore similar moon phases occurred both before and after fire. Although a substantial effort was made to recapture all collared animals to remove their collars, we only managed to recapture four of the six individuals and removed their collars.

\section{Analysis}

The cumulative number of fixes was plotted against increase in home range area to determine the minimum number of fixes required to give a precise home range estimate (Kenward 1987). This was done by calculating the home range of each individual after 10, 20, 30, 40 and 50 fixes. The differences between each home range estimate calculated in each group of fixes were then compared using ANOVA. Twenty fixes were required before there was no significant increase (ANOVA with Tukey's post-hoc tests: $P>0.05)$. All individuals with over 20 fixes pre-fire $(n=9)$ were used to calculate home ranges in the un-burnt habitat. Only individuals with over 20 fixes pre- and post-fire $(n=6)$ were used to investigate differences in home range, habitat use and activity patterns.
Home ranges for each animal were calculated using all fixes, pre- and post-fire, respectively, in ArcView GIS version 3.2 (ESRI 1992) and 'Animal Movement' extensions (Hooge \& Eichenlaub 1997). Home ranges were calculated using Kernel Home Range (KHR) estimator methods (95\% and $50 \%$ ) (Worton 1989). Kernel estimators provided a GIS-based grid coverage showing the utilization distribution (probabilities) of individual mammal activity in the area surveyed. The use of Kernel methods allowed the final range estimates to reflect whether some areas had been used more frequently than others, by assigning higher weightings to these areas. Activity patterns were investigated using successive Straight Line Distance (SLD) between fixes. As time between each fix varied, the successive distance moved were standardized by dividing by time, giving a 'rate of movement'.

To determine habitat use, the proportion of fixes located in each habitat type (grassland or thicket), was calculated. The proportion of thicket area within each final home range area was calculated by intersecting the thicket area with the home range polygon or contour in the digitized habitat map, and comparing this pre- and post-fire.

\section{Radio-tracking statistics}

Differences in home range area between the sexes were investigated using a $t$-test, and differences pre- and post-fire using a paired $t$-test. The mean successive SLD and mean rate of movement data were normally distributed. Differences in the proportion of fixes recorded in either grassland or thickets, pre- and post-fire, were tested using Wilcoxon signed rank test. A $t$-test was used to test differences in activity between the two time periods and a paired $t$-test was used to test for differences in activity pre- and post-fire. All data were analysed using SPSS (version 12).

\section{RESULTS}

\section{Home range area}

Overall 136 hours of radio-tracking was carried out, resulting in 904 triangulations. Eleven (six males, five females) E. brachyrhynchus were collared, six of which had a sufficient number of fixes to enable pre- and post-fire home range comparisons. The signal from two of the males was lost before enough fixes were collected to calculate pre-fire home ranges. Three other males had sufficient fixes pre-fire to calculate home 
Table 1. Mean number of fixes and home range area estimates including $95 \% \mathrm{KHR}$, and $50 \% \mathrm{KHR}( \pm 1 \mathrm{~S} . \mathrm{E}$. in brackets).

\begin{tabular}{lcccc}
\hline & $n$ & Mean fixes (range) & Mean 95\% kernel (S.E.) (ha) & Mean 50\% kernel (S.E.) (ha) \\
\hline $\begin{array}{l}\text { Females } \\
\text { Pre-fire }\end{array}$ & 5 & $67(48-90)$ & $0.25(0.07)$ & $0.03(0.01)$ \\
$\begin{array}{l}\text { Post-fire } \\
\text { Males }\end{array}$ & 5 & $58(56-59)$ & $0.17(0.17-0.09)$ & $0.02(0.01)$ \\
Pre-fire & & & & $0.07(0.02)$ \\
Post-fire & 4 & $56(39-72)$ & $0.41(0.08)$ & 0.04 \\
All individuals & 1 & 55 & 0.24 & $0.03(0.01)$ \\
Pre-fire & 9 & $62(39-90)$ & $0.24(0.06)$ & $0.02(0.01)$ \\
Post-fire & 9 & $57(55-59)$ & $0.18(0.07)$ & \\
\hline
\end{tabular}

ranges. However, these signals were lost before the fire, so data for post-fire comparisons were limited to one male and five females.

The fire was deliberately lit by the reserve manager and burnt an area of 13 ha in 45 minutes. Fire removed the grass layer, reducing mean sward height from $100 \pm 11.2 \mathrm{~cm}$ (S.E.) pre-fire to $2.5 \pm 0.5 \mathrm{~cm}$ high stubble post-fire. The thickets remained relatively intact, only receiving slight burning round the edges (R. Yarnell pers. obs.) as there was no grass in the understorey of the thickets.

All collared individuals were found immediately after the fire sheltering in termite mounds. There was no significant difference between male and female home range area ( $t$-test: d.f. $=7, P>0.05$; Table 1) and all further analyses were conducted irrespective of sex. There was no significant difference in any home range area before or after the fire event (paired $t$-test: $n=5$, d.f. $=5, P>0.05$; Table 1).

\section{Activity}

Male and female E. brachyrhynchus were equally active ( $t$-test: d.f. $=7, P>0.05)$, with the mean distance travelled and rate of movement between fixes before the fire for males $(n=4) 20.5 \pm 0.87 \mathrm{~m}$ and $36 \pm 4.4 \mathrm{~m} / \mathrm{h}$, respectively, and for females $(n=5) 16.2 \pm 1.7 \mathrm{~m}$ and $27.2 \pm 4.3 \mathrm{~m} / \mathrm{h}$, respectively. Therefore, activity data were analysed irrespective of sex. Pre-fire, E. brachyrhynchus travelled significantly greater straight line distances (SLD) and at greater speeds at night than during the day, respectively (Fig. 1, Table 2). Post-fire, E. brachyrhynchus continued to travel significantly greater distances at night than by day, but not at greater speeds. Therefore day and night activity were analysed separately. There were no significant differences in distance travelled or speed after the fire, during the day or night, respectively.

\section{Small-scale habitat preferences}

Fire caused E. brachyrhynchus to alter its habitat use (Table 3). Individuals utilized the adjacent unburnt area more after the fire than they did prefire. Post-fire, the number of fixes of two individuals in the unburnt area increased from $7 \%$ to $30 \%$ and from $9 \%$ to $27 \%$, respectively. An additional individual began utilizing this unburnt area post-fire $(70 \%$ of fixes being recorded there with $96 \%$ of these being recorded during the day).

Pre-fire there was a tendency for animals to range over a greater area $(95 \%$ KHR only; Wilcoxon signed-rank test: $z=-2.201, P=0.028$ ), and to have a greater area of grassland within their home range at night than there was during the day (both

Table 2. $t$-Statistics from paired $t$-tests on the Elephantulus brachyrhynchus movement [Straight Line Distance (SLD) and speed ( $\mathrm{m} /$ hour)] comparing day and night movements, pre- and post-fire; $t$-values are given and * denotes $P$-value $<0.05$.

\begin{tabular}{lccccc}
\hline & \multicolumn{2}{c}{ Day vs night } & & \multicolumn{2}{c}{ Pre-fire vs post fire } \\
\cline { 2 - 3 } & Pre-fire $(n=9)$ & Post fire $(n=6)$ & & Day $(n=6)$ & Night $(n=6)$ \\
\hline SLD & $-3.037^{*}$ & $-2.678^{*}$ & & 2.390 & 2.142 \\
Speed (m/hour) & -2.738 & -2.488 & & 0.728 & 1.304 \\
\hline
\end{tabular}



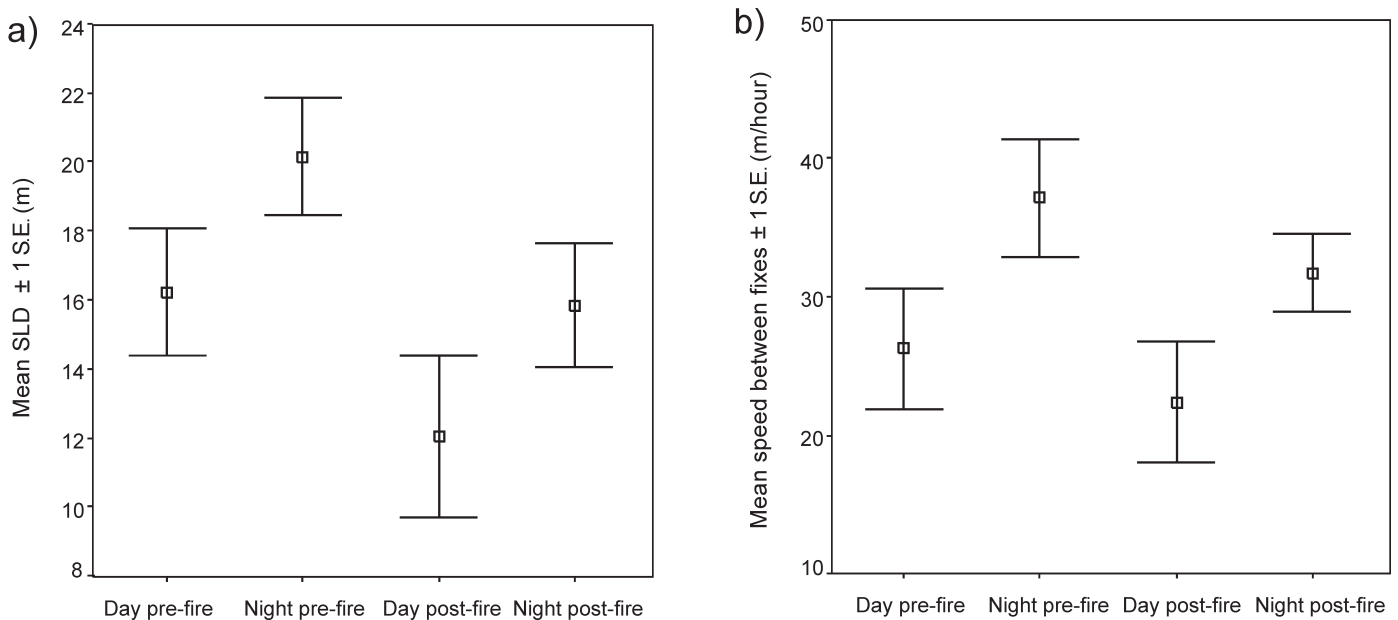

Fig. 1. Mean straight line distance a) and rate of movement b) between fixes of elephant shrews during day and night, pre- and post fire. Both indices of activity were higher during the night than day (paired $t$-test: $P<0.05$ ). There was no difference in activity indices after fire (paired $t$-test: $P>0.05$ ).

95\% and 50\% KHR, Wilcoxon signed-rank test: $P<0.05$; Table 3). Animals also spent a disproportionate amount of time in the thicket habitat during the day for 95\% KHR (Wilcoxon signed-rank test: $z=-2.201, P=0.028)$, but not for $50 \%$ KHR (Wilcoxon signed-rank test: $z=-1.782, P=0.075$ ). Post-fire the mean home range area decreased significantly at night for both $95 \%$ and $50 \%$ KHR (Wilcoxon signed-rank test: $P<0.05)$ and during the day for the $50 \%$ KHR (Wilcoxon signed-rank test: $z=2.201, P=0.028$ ). There was no decline in diurnal $95 \%$ KHR post-fire (Wilcoxon signed-rank test: $z=-1.572, P=0.116)$. There was also a greater decline in the area of grassland used at night than the area of thicket, and a further increase in the time spent in thicket areas (for both $95 \%$ and $50 \%$ KHR; Wilcoxon signed-rank test: $P<0.05$ ), but not during the day (for both $95 \%$ and $50 \%$ KHR; Wilcoxon signed-rank test: $P>0.05$ ).

To assess whether E. brachyrhynchus were selecting thicket habitats, the proportion of fixes in thickets was compared with the area available within 95\% KHR (Table 3). During the day, pre- and post-fire E. brachyrhynchus were selecting thicket habitat more often than grassland (Wilcoxon signed-rank test: $z=-2.201, P=0.026$ for both). At night, pre-fire, thicket habitat was not selected, (Wilcoxon signed-rank test: $z=-0.734$, $P=0.436)$, whereas post-fire, thicket habitat was preferred over grassland (Wilcoxon signed-rank

Table 3. Mean animal $(n=6)$ kernel home range estimates (95 and $50 \%)$ and the mean area of thicket, grassland, proportion of thicket and proportion of fixes in thickets contained in each home range during the day and night, preand post-fire at MWR.

\begin{tabular}{|c|c|c|c|c|c|}
\hline \multirow{2}{*}{$\begin{array}{l}\text { Kernel home } \\
\text { range est. }\end{array}$} & \multirow[t]{2}{*}{ Variables } & \multicolumn{2}{|c|}{ Day } & \multicolumn{2}{|c|}{ Night } \\
\hline & & Pre-fire & Post-fire & Pre-fire & Post-fire \\
\hline \multirow[t]{5}{*}{$95 \%$} & Mean home range size (ha) & 0.21 & 0.10 & 0.25 & 0.13 \\
\hline & Mean area of thicket within home range (ha) & 0.07 & 0.04 & 0.06 & 0.04 \\
\hline & Mean area of grassland within home range (ha) & 0.14 & 0.06 & 0.19 & 0.09 \\
\hline & Mean \% thicket area within home range (S.E.) & $35.02(3.89)$ & $45.17(10.95)$ & $24.09(2.97)$ & $37.34(4.99)$ \\
\hline & Mean \% fixes in thicket habitat (S.E.) & $47.64(4.80)$ & $59.24(9.06)$ & $30.15(6.64)$ & $58.62(6.68)$ \\
\hline \multirow[t]{4}{*}{$50 \%$} & Mean home range size (ha) & 0.03 & 0.02 & 0.04 & 0.02 \\
\hline & Mean area of thicket within home range (ha) & 0.01 & 0.01 & 0.01 & 0.01 \\
\hline & Mean area of grassland within home range (ha) & 0.02 & 0.01 & 0.03 & 0.01 \\
\hline & Mean \% thicket area within home range (S.E.) & $46.66(6.10)$ & $68.42(9.75)$ & $25.59(7.36)$ & $59.26(7.24)$ \\
\hline
\end{tabular}


test: $z=-1.992, P=0.046)$.

\section{DISCUSSION}

Interpretation of results was constrained by the low numbers of collared individuals. Eleven E. brachyrhynchus were initially collared, although signals from five males were lost during the study period. This is common in small mammal radiotracking and may be attributed to males not holding territories and/or being more transient than females (Montgomery 1989). Consequently, only one male home range was compared pre- and post fire. This showed similar habitat use and shifts to females, which suggests that fire response in this species regardless of sex. Owing to feasibility and logistics, more fixes were recorded during the day than at night. On average during pre-fire, only 14 fixes were collected per night, which may have underestimated range area. Despite the low sample size and limited night fixes, pre-fire patterns are evident, supporting the validity of results.

Many studies investigating the effect of fire have speculated that small mammals may survive the initial passage of fire, and that post-fire declines are caused by increased predation and a reduction in food (e.g. Cheeseman \& Delany,1979; Swanepoel 1981; Monadjem \& Perrin 1997; Kern 1981). In our study, E. brachyrhynchus survived fire passage in termite mounds, substantiating other findings of burrows being used as refugia during fires (Cheeseman \& Delany 1979; Swanepoel 1981; Monadjem 1999). The use of burrows is uncommon in most Elephantulus spp. (Skinner \& Chimimba 2005) and may be an adaptive response to fire. In this study, E. brachyrhynchus commonly used sisal in the thickets for shelter, and only used termite mounds during the fire. The closely related $E$. intufi usually shelters under rocks, but has also been reported to use burrows (Rathbun \& Rathbun 2006).

In our study, the 'cold burn' fire changed the structure and availability of the remaining habitat. It removed the grass layer to leave relatively large open spaces between unburned patches of thicket. The fire did not penetrate into the thickets, possibly as a consequence of its low intensity, low grass cover in the thicket understorey and the low flammability of sisal. E. brachyrhynchus altered habitat use in response to this fire-induced habitat modification. Before the fire E. brachyrhynchus spent most of the day in protective sisal thickets, with home ranges centred on this habitat. How- ever, at night animals were more often located in the grassland. As reported in the study by Woodall et al. (1989) on captive individuals, E. brachyrhynchus were more active at night. After fire, thicket utilization increased disproportionately. Utilization of burned grassland decreased, and thickets were used more during peak activity periods. Therefore, reduction in cover and resultant increased predation risk are the most likely explanations for shifts in habitat use after fire (Kotler et al. 2004). Lack of cover influences foraging, whereby individuals spend less time in open habitats due to a presumed increased perception of predation risk (Mohr et al. 2003; Ziv \& Kotler et al. 2004; Kotler et al. 2004).

Home range area is resource dependent (Fitzgibbon 1995). All previous studies on elephant shrews report large variation in individual home range area, possibly due to variable levels of food availability (e.g. Rathbun 1979; Fitzgibbon 1995). In our study, no individuals moved away from their pre-fire home range after the fire, indicating food resources immediately post-fire were sufficient for home range to be maintained in the short term. This, combined along with reductions in home range size, suggests food availability was not the main factor for the recorded response to fire. Hence the reduction in range and shift to thicket habitats is likely to be a response to removal of cover and increased risk of predation in open areas (Hughes et al. 1994; Kotler et al. 2004).

This study is the first to quantify survival during fire for elephant shrews. We also show that the fire in this study had no negative impact on the E. brachyrhynchus population during the study period; they remained in the area and adjusted habitat use. Radio-tracking studies on other species in habitats prone to fire will need to be conducted to determine how general this response is. Our (preliminary) evidence shows that individuals alter behaviour immediately post-fire, but it is not known if habitat changes will have longer term detrimental effects on survival, emigration and immigration rates or reproduction. In this study the fire was a diurnal cold burn, burning against the wind at low intensity leaving 'islands' of remaining vegetation cover. Not all fires in savanna ecosystems are similar, and generally there is a lack of information on the effect of fire on small mammal communities at different spatial and temporal scales, seasons and intensities (Parr \& Chown 2003). Since the majority of rodents in South Africa are burrow-dwelling nocturnal 
species (Skinner \& Chimimba 2005), it is suggested they would survive diurnal fast or cool burn fires. Other studies have shown that fires which leave islands of vegetation provide adequate cover for small mammals and have limited if any effect on populations (Bowland \& Perrin 1988). The effects of 'clean burns' that leave no cover, or those that are burnt at night when most small mammals are active (Skinner \& Chimimba 2005), or covering large spatial scales with little adjacent substitute or refuge habitat, are hypothesized to have a much greater impact on small mammals. Further research over longer time periods is needed to investigate the impact of different fire regimes on small mammal ecology.

In conclusion, this study shows that E. brachyrhynchus survives the initial passage of fire by sheltering in termite mounds. The fire-induced habitat modification restricted their movements to patches of unburned vegetation that provided cover which is likely to be an anti-predator response. This study also highlights the importance of islands left behind after fire to E. brachyrhynchus persistence.

\section{ACKNOWLEDGEMENTS}

The research was funded by a University of Brighton Studentship with some equipment supplied by Durham University, U.K. Mammal Research Institute staff at University of Pretoria provided further guidance and support. We are grateful to Sam Parsons and Lucy Alesbury, who assisted radio-tracking in the field. Thanks to Dougal McTavish and Lynne Levitt for site permission and support during fieldwork. Steve Waite and Liz Cheek made useful comments on statistics and Caroline Bruce and Adam McKeown made useful comments on a draft manuscript. British Airways and the Royal Geographic Society provided travel support to R.W.Y.

\section{REFERENCES}

ACOCKS, J.P.H. 1975. Veld types of South Africa. Memoirs of the Botanical Survey of South Africa No. 57, 51-55. Botanical Research Institute, Department of Agriculture and Water Supply, South Africa.

BOWERS, M.A. \& DOOLEY, J.L. 1993. Predation hazard and seed removal by small mammals: microhabitat versus patch scale effects. Oecologia 94: 247-254.

BOWLAND, A.E. \& PERRIN, M.R. 1988. The effect of fire on the small mammal community in Hluhluwe Game Reserve. International Journal of Mammalian Biology 53: 235-244.

BROCKETT, B.H., BIGGS, H.C. \& VAN WILGEN, B.W. 2001. A patch mosaic burning system for conserva- tion areas in southern African savannas. International Journal of Wildland Fire 10: 169-183.

CHEESEMAN, C.L. \& DELANY, M.J. 1979. The population dynamics of small rodents in a tropical African grassland. Journal of Zoology 188: 451-475.

CLARK, B.K. \& KAUFMANN, D.W. 1990. Short term responses of small mammals to experimental fire in tallgrass prairie. Canadian Journal of Zoology 68: 2450-2454.

COCKRAN, W.W. 1980. Wildlife telemetry. In: Wildlife Management Techniques Manual, (ed.) S.D. Schemnity, pp. 507-520. The Wildlife Society, Washington.

CORBET, G.B. \& HANKS, J. 1968. A revision of the elephant-shrews, family Macroscelididae. Bulletin of the British Museum (Natural History), Zoology 16: 47-111.

ENVIRONMENTAL SYSTEMS RESEARCH INSTITUTE 1992, ArcView GIS 3.2. ESRI, USA.

FITZGIBBON, C.D. 1995. Comparative ecology of two elephant-shrew species in a Kenyan forest. Mammal Review 25: 19-30.

FRIEND, G.R. 1993. Impact of fire on small mammal vertebrates in Mallee woodlands and heathlands of temperate Australia - A review. Biological Conservation 65: 99-114.

FULLER, J.A. \& PERRIN, M.R. 2001. Habitat assessment of small mammals in the Umvoti Vlei Conservancy, KwaZulu-Natal, South Africa. South African Journal of Wildlife Research 31: 1-12.

HOFFMAN, A. \& KLINGEL, H. 2001. Spatial and temporal patterns in Lemniscomys striatus Linnaeus 1758 as revealed by radio-tracking. African Journal of Ecology 39: 351-356.

HOOGE P.N. \& EICHENLAUB, B. 1997. Animal movement extension to ArcView. Version 1.1. Alaska Biological Science Centre, U.S. Geological Survey, Anchorage, Alaska, U.S.A.

HUGHES, J.J., WARD, D. \& PERRIN, M.R. 1994. Predation risk and competition affect habitat selection and activity of Namib gerbils. Ecology 75: 1397-1405.

KENWARD, R. 1987. Wildlife Radio Tagging: Equipment, Field Techniques and Data Analysis. Academic Press, London.

KERN, N.G. 1981. The influence of fire on populations of small mammals of the Kruger National Park. Koedoe 24: $125-157$.

KOTLER, B.P., BROWN, J.S. \& BOUSKILA, A. 2004. Apprehension and time allocation in gerbils: the effects of predatory risk and energetic state. Ecology 85: 917-922.

LEIRS, H., VERHAGEN, R., VERHEYEN, W. \& PERRIN M.R. 1995. The biology of Elephantulus brachyrhynchus in natural Miombo woodland in Tanzania. Mammal Review 25: 45-49.

LINZEY, A.V. \& KESNER, M.H. 1997. Small mammals of a woodland-savannah ecosystem in Zimbabwe.1. Density and habitat occupancy patterns. Journal of Zoology 243: 137-152.

MOH, R.K., VIBE-PETERESEN, S., JEPPESEN, L.L., BILDSOE, M. \& LEIRS, H. 2003. Foraging of multimammate mice, Mastomys natalensis, under different predation pressure: cover, patch-dependent decisions and density-dependent GUDs. Oikos 100: $459-468$. 
MONADJEM, A. 1999. Population dynamics of Mus minutoides and Steatomys pratensis (Muridae: Rodentia) in a subtropical grassland in Swaziland. African Journal of Ecology. 37: 202-210.

MONADJEM, A. \& PERRIN, M.R. 1997. Population dynamics of Lemniscomys rosalia Muridae: Rodentia in a Swaziland grassland: effects of food and fire. South African Journal of Zoology 32, 129-135.

MONADJEM, A. \& PERRIN, M. 2003. Population fluctuations and community structure of small mammals in a Swaziland grassland over a three-year period. African Zoology 38: 127-137.

MONTGOMERY, W.I. 1989. Population regulation in the wood mouse, Apodemus sylvaticus. 2. Density dependence in spatial distribution and reproduction. Journal of Animal Ecology 58(2): 477-494.

NEAL, B.R. 1995. The ecology and reproduction of the short snouted elephant shrew, Elephantulus brachyrhynchus, in Zimbabwe with a review of the reproductive ecology of the genus Elephantulus. Mammal Review 25: 51-60.

PARR, C.L. \& CHOWN, S.L. 2003. Burning issues for conservation: a critique of faunal fire research in Southern Africa. Austral Ecology. 28: 384-395.

RANKIN, J.J. 1965. Notes on the ecology, capture and behaviour in captivity of the elephant shrew Nasilio brachyrhynchus brachyrhynchus. Zoologica africana 1: 73-80.

RATHBUN, G.B. 1979. The social structure and ecology of elephant-shrews. Advances in Ethology 20: 25-48

RATHBUN, G.B. \&. RATHBUN, C.D. 2006. Social structure of the bushveld sengi Elephantulus intufi in Namibia and the evolution of monogamy in the Macroscelidea. Journal of Zoology 269(3): 391-399.

SCOTT, D.M. \& DUNSTONE, N. 2000. Environmental determinants of the composition of desert-living rodent communities in the north-east Badia region of Jordan. Journal of Zoology 251: 481-494.

SKINNER, J.D. \& CHIMIMBA, C.T. 2005. Mammals of the Southern African Subregion (3rd edn). Cambridge University Press, Cape Town

STUART, C., PERRIN, M., FITZGIBBON, C., GRIFFIN, M. \& SMIT, H. 2006. Elephantulus brachyrhynchus. In:
2006 IUCN Red List of Threatened Species. IUCN, Gland, Switzerland.

SUTHERLAND, E.F. \& DICKMAN, C.R. 1999. Mechanisms of recovery after fire by rodents in the Australian environment: a review. Wildlife Research 26, 405-419

SWANEPOEL, C.M. 1981. The effect of fire on a small mammal community. South African Journal of Zoology 16: 232-236.

TARABORELLI, P.A., DACAR, M. \& GIANNONI, S.M 2003. Effect of plant cover on seed removal by rodents in the Monte Desert Mendoza, Argentina. Austral Ecology 28: 651-657.

VAN OUDTSHOORN, F. 2002. Guide to Grasses of Southern Africa. Briza Publications, Pretoria.

VAN HENSBERGEN, H.J. \& MARTIN, S.C. 1993. Climatic factors affecting trapping success of some South African small mammals. South African Journal Wildlife Research 23: 87-94.

VIEIRA, E.M. 1999. Small mammal communities and fire in Brazilian Cerrado. Journal of Zoology 249: 75-81.

WHELAN, R.J. 1995. The Ecology of Fire. Cambridge University Press.

WOODALL, P.F., WOODALL, L.B. \& BODERO, D.A.V. 1989. Daily activity patterns in captive elephant shrews Macroscelididae. African Journal of Ecology 27: 63-76

WORTON, B.J. 1989. Kernel methods for estimating the utilization distribution in home range studies. Ecology 70: 164-168.

YARNELL, R.W. 2006. The effect of game ranch management on small mammal communities in a bushveld area of South Africa. Ph.D. thesis, University of Brighton.

YARNELL, R.W. \& SCOTT, D.M. 2006. Notes on the ecology of the short-snouted elephant shrew Elephantulus brachyrhynchus at a game ranch in North-west Province, South Africa. Afrotherian Conservation Newsletter, IUCN, Gland, Switzerland.

ZIV, Y. \& KOTLER, B.P. 2003. Giving-up densities of foraging gerbils: the effect of interspecific competition on patch use. Evolutionary Ecology 17: 333-347. 